\title{
$\mathrm{ERCP}$ 를 시작하는 의사가 알아야 하는 기본 지식들
}

부산대학교 의과대학 양산부산대학교병원 내과

이정욱 · 남형석

\section{Basic Knowledge that Doctors Starting ERCP Should Know}

\author{
Jung Wook Lee, Hyeong Seok Nam \\ Department of Internal Medicine, Pusan National University Yangsan Hospital, Pusan National University School of Medicine, Yangsan, Korea
}

The first endoscopic retrograde cholangiopancreatography (ERCP) wad performed in 1968. With tremendous progress in techniques, instruments and devices, ERCP has played an important role in modern medicine for the diagnosis and management of various pancreaticobiliary diseases. ERCP has a potential risk of various complications even in the hands of the experts. The incidence of all ERCP-related complications is known to be about $4-10 \%$, and that of fatal complications to be less than $0.5 \%$. In order to prevent and minimize its side effects, the everyone who performs ERCP needs to fully understand various techniques and also recognize and deal with ERCP-related complications. In this review, we have summarized the must-know points in techniques and complications of ERCP for the beginners.

Korean J Pancreas Biliary Tract 2021;26(2):89-97

Keywords: Cholangiopancreatography, endoscopic retrograde, Therapeutics, Complications $\begin{array}{ll}\text { Received } & \text { Mar. 12, } 2021 \\ \text { Revised } & \text { Apr. 20, } 2021 \\ \text { Accepted } & \text { Apr. 20, } 2021\end{array}$

Corresponding author: Hyeong Seok Nam Department of Internal Medicine, Pusan National University Yangsan Hospital, Pusan National University School of Medicine, 20 Geumo-ro, Mulgeum-eup, Yangsan 50612, Korea

Tel: +82-55-360-1531 Fax. +82-55-360-1536

E-mail; skyace27@hanmail.net

ORCID: https://orcid.org/0000-0001-5827-5080
This is an Open Access article distributed under the terms of the Creative Commons Attribution Non-Commercial License (http:// creativecommons.org/licenses/by-nc/3.0/) which permits unrestricted non-commercial use, distribution, and reproduction in any medium, provided the original work is properly cited.

Copyright $@ 2021$ by The Korean Journal of Pancreas and Biliary Tract

\section{서 론}

내시경역행담췌관조영술(endoscopic retrograde cholangiopancreatography, ERCP)은 1968년 처음 시행된 이후 다양한 췌장담도 질환의 진단과 치료에 있어 기본적이며 중요한 시술이 되었다. 그러나 ERCP는 다른 내시경 시술에 비해 상대적으로 시술의 위험 요소가 크며, 여러 합병증을 동반할 수 있어 부작용을 최소화하고 안전하게 시행할 수 있도록 여러 술기를 숙지하는 것이 중요하다. 또한 합병증이 발생할 경우 이에 대한 적절한 대처가 필요하다. 전체 $\mathrm{ERCP}$ 합병증 발생률은 $4-10 \%$ 정도로 보고되고 있으며, 중대한
합병증은 $0.5 \%$ 미만으로 알려져 있다. 본고에서는 $\mathrm{ERCP}$ 를 시작하는 의사가 알아야 하는 다양한 가이드라인의 종합적인 내용과 합병증 및 이에 대한 대처 방법에 대하여 간략히 다루어 보고자 한다.

\section{본 론}

\section{ERCP 적응증}

ERCP는 시술과 관련된 심각한 합병증이 발생할 수 있어 적절한 적응증에 해당하는 환자를 선별하여 꼭 필요한 
환자에게만 시행해야 한다. 현재 $\mathrm{ERCP}$ 는 치료 목적으로 주로 시행되고 있으며 과거 진단 목적의 $\mathrm{ERCP}$ 는 자기공명영상 검사 및 초음파 내시경 등의 검사로 대체할 수 있게 되었다. 미국 소화기내시경학회에서 인정한 $\mathrm{ERCP}$ 적응증과 비적응증은 Table 1과 같다. ${ }^{1}$

\section{2. 선택적 담관 삽관술}

성공적인 담관 삽관은 담관에 대한 모든 치료 및 검사를 위하여 반드시 선행되어야 한다. $\mathrm{ERCP}$ 를 실패하는 가장 흔한 원인은 선택적 담관 삽관의 실패이고, 담관 삽관 시도 횟수가 증가하면 $\mathrm{ERCP}$ 관련 합병증이 증가한다. 담관 삽관 성공률에 대한 유두 괄약근 절개도(sphincterotome)와 ERCP 도관(catheter)의 무작위 대조 연구에서 $84 \%$ vs. $62 \%$ ( $p<0.05)$ 로 전자가 우수한 결과를 보여주었다. ${ }^{2,3}$ 이는 유두 괄약근 절개도에는 유연한 끝이 있고 각도 조절이 가능하여 상방 보기 자세(look-up position)를 가능하게 하며, 끝을 적절한 축으로 조정하는 데 유리하고 $\mathrm{ERCP}$ 도관 삽관에 비하여 유두 괄약근 절개도 삽관에 따른 합병증 증가는 보이지 않았다 $(p=0.30) .{ }^{4}$

\section{3. 내시경 유두 괄약근 절개술}

내시경 유두 괄약근 절개술(endoscopic sphincterotomy, EST)이란 유두 괄약근 절개도를 주유두부(major papilla)를 통하여 담관에 삽관한 후 고주파 전류를 이용하여 절개하는 시술을 말한다. 담관 담석의 제거에 있어 EST를 이용한 내시경 치료와 수술을 비교한 메타분석 연구에 의하면 담석 제거율, 사망률과 합병증 발생률에 있어 통계학적 유의한 차이가 없었다. ${ }^{5}$

2020년 ERCP 합병증에 대한 European Society of Gastrointestinal Endoscopy 가이드라인에 제시된 출혈 합병증 위험도에 따르면 EST는 고위험 시술(high risk procedure)로 new oral anticoagulants이나 클로피도그렐 등의 항혈소판제 복용, 급성 췌장염 환자에서 시행하는 것은 상대적 금기이다. ${ }^{6}$ 대규모 전향 분석에 따르면 아스피린과 비스테로이드 항염증제는 EST 후 출혈의 위험인자가 아닌 것으로 확인되었다. ${ }^{7}$ 항혈소판제의 지속 혹은 중단은 EST 후 출혈에 유의미한 영향을 미치지 않았다 (continuation odds ratio [OR] 0.67; 95\% confidence interval [CI] 0.21-2.11, and withdrawal OR 1.25; 95\% CI 0.90-1.74). ${ }^{8}$ 그러나 비아세틸 살리실산 항혈소판제제는 중단해야 한다. ${ }^{6}$
EST 후 출혈의 위험인자로는 만성 신부전, 고혈압, 심장 질환, 간경변증, 혈소판 수 감소, international normalized ratio level 증가 및 항혈소판제 복용 등이 있다. ${ }^{9}$ 시술 전 교정 가능한 위험인자를 미리 교정 후 절개술을 시행해야 EST 후 출혈을 예방할 수 있다. ${ }^{9}$ EST 시 사용되는 고주파 전류의 종류에 따라서도 출혈 위험도는 달라지는데, 절단파(cutting wave)의

Table 1. Indications and contraindications of ERCP (modified from American Society for Gastrointestinal Endoscopy ${ }^{1}$ )

내시경역행담췌관조영술이 필요한 경우

A. 담도 폐쇄 의심

B. 황달은 없으나 췌관 또는 담도 질환을 시사하는 임상 및 생화학 또 는 영상 검사 결과가 나온 경우

C. 췌장 악성 종양 시사하는 증상 또는 징후가 있으나 영상 검사(예, EUS, 복부 초음파, CT, MRI)에서 확실하지 않은 경우

D. 췌장염 원인 평가

E. 만성 췌장염이나 췌장 가성 낭종의 수술 전 평가

F. Oddi 괄약근 압력 측정

$\mathrm{G}$. 내시경 괄약근 절개술:

1. 총담관석

2. 유두부 협착 또는 Oddi 괄약근 기능 이상

3. 담도 스텐트 삽입 또는 담도 협착의 확장

4. Sump 증후군

5. 주유두 침범 총담관류

6. 수술 대상이 되지 않는 주요 유두부암

7. 췌관 질환 내시경 시술

H. 양성 또는 악성 협착, 누공, 수술 후 담즙 누출, 제거불가한 큰 총담 관석을 갖는 고위험 환자에서 스텐트 삽입

I. 담관 또는 췌관 협착의 확장

J. 유두의 풍선 확장

K. 경비 배액관 삽입

L. 가성 낭종 배액

M. 췌관 또는 담관 조직 검사

N. 주유두 선종 신생물의 팽대부절제술

O. 담도와 췌관 질환 치료

P. 담관경 또는 췌관경 검사

내시경역행담췌관조영술의 적응증에 해당하지 않는 경우

A. 진단 목적의 내시경역행담췌관조영술(자기공명담췌관조영술 및 초음파 내시경으로 대체)

B. 담관 질환의 증거가 없는 담낭 질환의 평가

C. 치료 계획 변화가 예상되지 않는 췌장 악성 종양의 추가 평가

$E R C P$, endoscopic retrograde cholangiopancreatography; EUS, endoscopic ultrasound; CT, computed tomography; MRI, magnetic resonance imaging. 
단독 사용보다 응고파(coagulation wave)를 동시에 사용하거나 Endocut 모드를 사용하는 것이 예기치 않은 절단(zipper cut)의 위험을 줄이며 출혈률을 감소시켰다. ${ }^{10}$ 따라서 췌장염 감소 및 출혈 위험도를 낮추기 위하여 Endocut 모드를 사용한다. ${ }^{10}$ 유두 괄약근 절개도에는 다양한 형태가 있으며 절개 철사 길이 $20 \mathrm{~mm}$ 와 $30 \mathrm{~mm}$ 의 비교 연구에서는 두 군 간 차이가 없었다. ${ }^{10}$

출혈과 절개 방향에 대한 연구에 따르면 10-11시 방향의 혈관 특히 동맥 분포는 $10-11 \%$ 로 낮아 출혈을 감소시키기 위해서는 11-12시 방향으로 절개하는 것이 좋다. ${ }^{11}$ 절개 크기는 가로주름 (transverse fold)을 넘지 않는 경우를 소절개, 유두부 돌출 부위(papillary bulge)의 상부 경계(superior margin)에 도달하면 대절개, 그 중간은 중절개로 분류한다(Fig. 1). 유두부 상부 괄약근(superior sphincter)은 십이지장 측벽(lateral wall)의 담관까지 확장되어 있으며 십이지장 내강내로 돌출된 유두부의 상연이 중간 괄약근(middle sphincter)에 해당한다. 따라서 유두부 상부 괄약근을 지나서 절개하면 천공의 위험이 증가하고 천공을 예방하기 위해 유두부 상연 이상으로 절개하지 않도록 주의해야한다.

EST에 사용되는 고주파 전류는 심박동기(cardiac pacemakers)나 삽입형 제세동기(implantable cardioverter-defibrillator)를 간섭할 수 있고 고장을 일으키거나 주요 작동 메커니즘을 손상시킬 수 있고 사망까지도 발생할 수 있다. ${ }^{12}$ 따라서 EST 전 순환기내과 전문의와 상담해야 한다. ${ }^{12}$ 완전 방실 차단의 경우 EST 전 $\mathrm{VOO}$ 또는 $\mathrm{DOO}$ 모드와같은 비동기화 방식(asynchronous setting)으로 변경하는 것이 좋다..$^{2}$ 또한 시술 시 심전도, 혈압 및 산소포화도 감시를 반드시 해야 한다. ${ }^{12}$

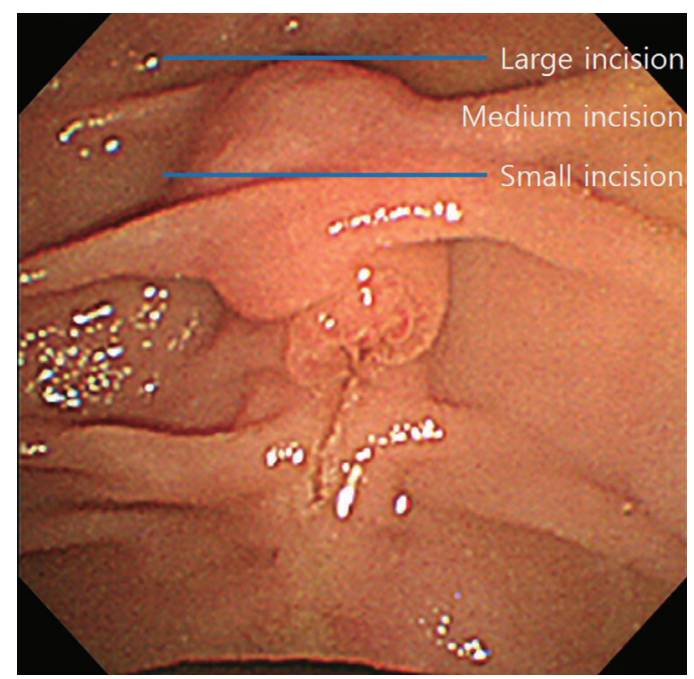

Fig. 1. Small incision, medium incision and large incision.
담석 췌장염(biliary pancreatitis) 환자에서 72시간 이내에 시행하는 조기 $\mathrm{ERCP}$ 를 시행한 군과 보존적 치료를 한 군 사이의 비교 연구에서는 사망률(relative risk [RR] 0.74; 95\% CI 0.18 to 3.03 ), 국소 및 전신 합병증 발생률(RR $0.86 ; 95 \% \mathrm{CI} 0.52$ to 1.43 ; and RR $0.59 ; 95 \%$ CI 0.31 to 1.11 respectively) 사이에 유의한 차이는 관찰되지 않았다. ${ }^{13}$ 그러나 담관염을 동반한 경우 조기 ERCP군에서 사망률(RR 0.20; 95\% CI 0.06-0.68), 국소 및 전신 합병증(RR $0.45 ; 95 \%$ CI 0.20-0.99; RR 0.37; 95\% CI 0.18-0.78)이 통계학적으로 유의하게 낮게 발생하였다. 또한 담관염 환자에서 담도 폐색이 동반된 경우 조기 $\mathrm{ERCP}$ 군이 국소 합병증(RR 0.54; 95\% CI 0.32-0.91) 발생이 유의하게 낮았다. ${ }^{13}$ 따라서 황달을 동반한 담석 췌장염의 경우 조기에 $\mathrm{ERCP}$ 를 시행하는 것이 강력히 권장된다.

\section{4. 예비 절개술(precutting sphincterotomy)}

선택 삽관이 어려운 경우 담관 삽관을 지속적으로 시도하는 것보다 예비 절개술을 이용하는 경우 담관 삽관율(deep biliary cannulation rate)이 더 높다. 그러나 출혈과 천공의 위험도 역시 증가하며 ERCP 후 췌장염의 발생률도 증가시킨다. ${ }^{14,15}$ 예비 절개술은 유두부 상부에서 원위부 방향이나 근위부 방향으로 절개하며 시술 중 4-38\%에서 시행되었으며 담관 선택 삽관의 성공률은 35-96\%로 보고되었다. ${ }^{2}$ 췌장 스텐트 삽관 후 예비 절개술을 진행하면 췌관의 방향을 확인하면서 담관 절개를 할 수 있으며 ERCP 후 췌장염을 예방할 수 있다. ${ }^{16}$ 예비 절개술은 유두 절개술보다 합병증이 더 많이 발생하므로 유두절개술로

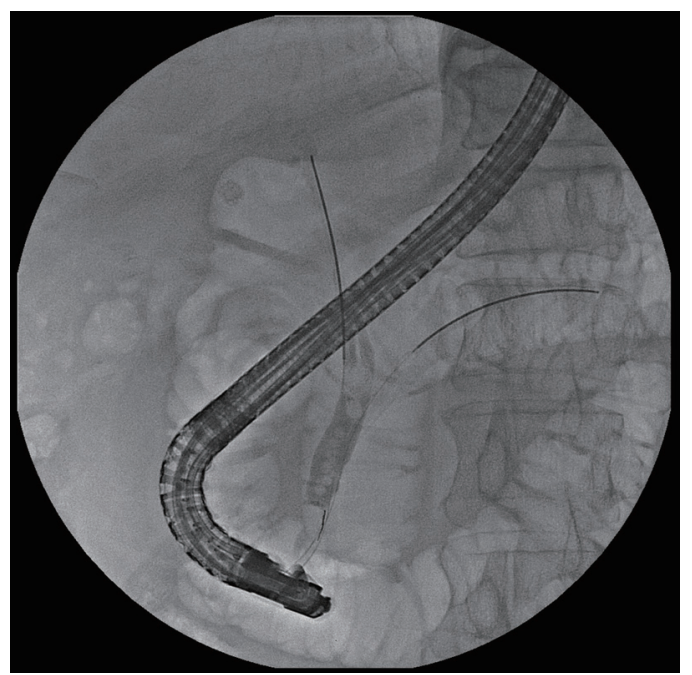

Fig. 2. Double guidewire technique. 
선택 삽관이 불가능할 경우 시도해야한다.

주췌관에 유도 철선이 삽관된 경우 이를 제거하지 않고 두 번째 유도철선을 사용하여 선택 삽관을 시도하는 이중 유도철선법(double guidewire technique) (Fig. 2) 또한 유두부를 안정화시키고, 공통관(common channel)을 직선화 시키며 유도철선(guidewire)을 아래 방향으로 이동시켰을 때 담관 입구가 개구되는 효과가 있어 담도 삽관을 보다 용이하게 해줄 수 있다. ${ }^{2}$ 담관 선택 삽관에 실패한 경우 endoscopic ultrasound (EUS) 유도하 $19 \mathrm{G}$ 바늘을 이용하여 간외 담도를 천자한 후 $260 \mathrm{~cm}$ 의 짧은 유도 철선을 삽입하여 유두를 통과시킨 후 십이지장경으로 변경하여 담관 선택 삽관을 시도하는 EUS 유도하 랑데뷰법(EUS guided rendezvous technique)도 최근 사용된다. ${ }^{17}$ 후향적 비교 연구에 따르면 EUS 유도하 랑데뷰법이 예비 절개술보다 우수한 담도 삽관율을 보여주었고(98.3\% vs. $90.3 \% ; p=0.03)$ 합병증 비율에는 유의한 차이가 없었다 $3.4 \%$ vs. $6.9 \%, p=0.27){ }^{17}$ 위에서 담관을 관찰하고 천자하는 경위

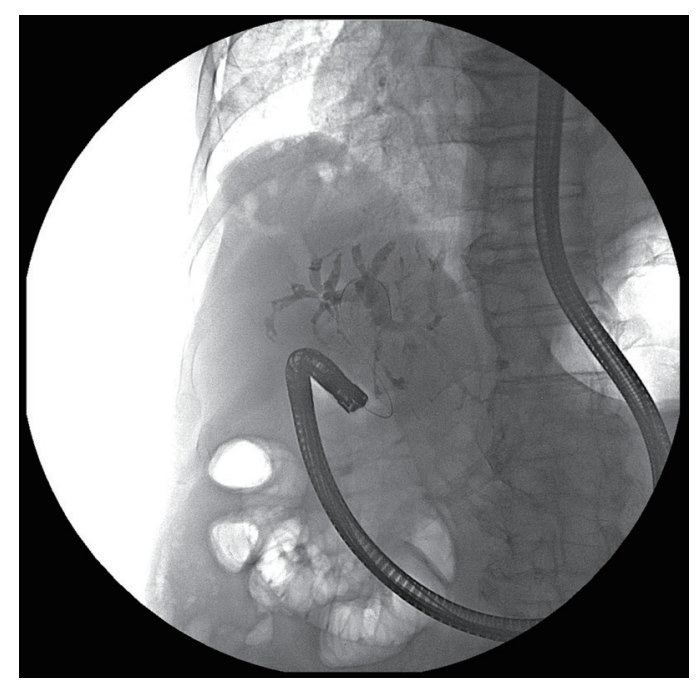

Fig. 3. Long scope position. 단축법(short scope position and transgastric approach)에서는 내시경을 일직선으로 펴고 시술할 수 있으며, 십이지장 구부에서 담관을 관찰하고 천자하면 내시경을 위의 대만을 따라 큰 원을 그리는 위치에 두고 밀면서 천자할 수 있다 (trans-duodenal approach, long scope position, push method) (Fig. 3). ${ }^{18}$ 천자 부위의 선택은 대개 해부학적 상태를 고려하여 결정한다.

\section{5. 십이지장 유두 주위 게실}

십이지장 유두 주위 게실(periampullary diverticulum)이 동반된 경우 게실과 유두의 관계에 따라 선택적 담관 삽관이 어려울 수 있으며 절개의 길이와 방향을 신중히 결정해야 한다. 유두 주위에 게실이 있는 경우에 게실이 없는 경우보다 EST 후 출혈이 더 많이 발생한다 $(8.8 \%$ vs. $4.8 \% ; p=0.039) .{ }^{19}$ 특히 유두가 게실 내 위치하는 십이지장 유두 주위 게실 1형(Fig. 4)인 경우, 겸자공으로 통해 조직 검사용 겸자를 삽입하여 십이지장 점막을 잡고 원위부로 이동시켜 유두를 게실 밖으로 이동시킨 후 고정한 상태에서, 겸자공으로 $\mathrm{ERCP}$ 도관을 삽입하여 선택 삽관을 진행하는 two devices-in-one-channel method 방법도 도움이 된다. ${ }^{20}$ 또 다른 방법으로는 내시경 클립을 이용하여 십이지장 유두 주위 게실 내 유두를 십이지장으로 이동시키는 방법도 있다. ${ }^{21}$

\section{6. 변형된 해부학적 구조}

위암 수술로 변형된 해부학적 구조를 가진 환자의 경우에도 EST 적응증은 정상 구조 환자와 동일하다. Billroth I 재건술을 받은 환자에서는 일반적인 EST과 같은 방식으로 한다. Billroth II 재건술을 받은 환자에서는 의료 기관의 선호에 따라
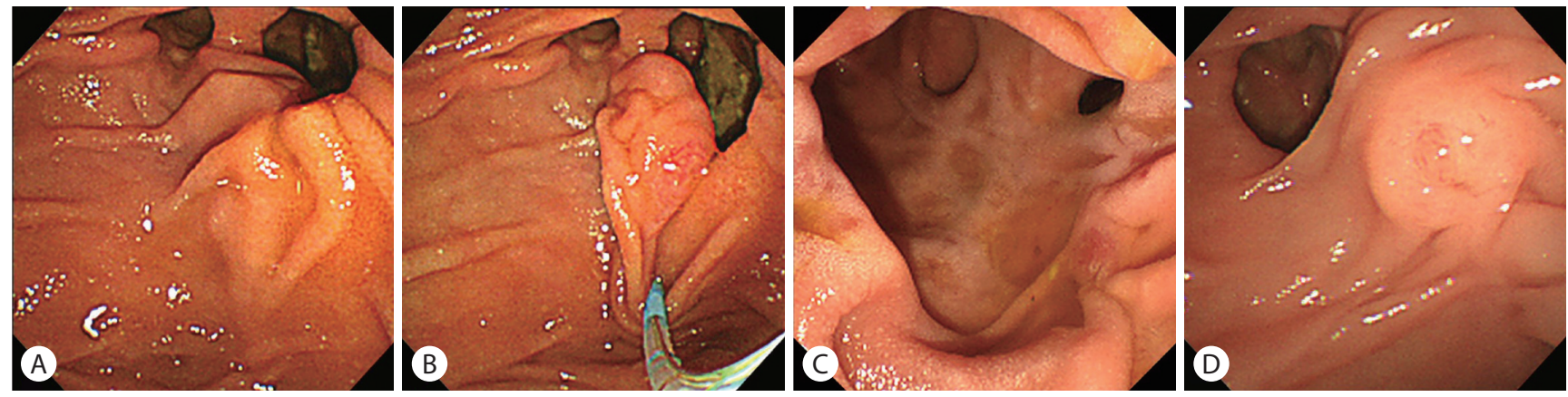

Fig. 4. Periampullary diverticulum types. (A) type 1, (B) type 1, (C) type 2, (D) type 3. 
직시경 (forward-viewing endoscope) 또는 측시경 등이 사용된다. ${ }^{22}$ 유두부 접근이 직시경 혹은 측시경으로 어려운 경우 풍선 소장내시경(balloon-enteroscope)을 이용하여 유두부에 접근 후 필요한 시술을 시행할 수 있다. ${ }^{23,24}$ Billroth II 환자의 EST 시에는 유두부가 항문 쪽(anal side)에서 접근되기 때문에 밀기형 유두 괄약근 절개도(push type sphincterotome) 같은 특수한 형태가 이용된다. ${ }^{23,24}$

변형된 구조를 가진 환자에서 직시경과 측시경 사이의 침형 절개도(needle knife)를 이용한 EST의 성공률에 대한 무작위 대조 시험에서 유의한 차이는 없었고( $80 \%$ vs. $83 \%)$, EST 관련 합병증은 유의한 차이가 없었다. ${ }^{25}$ 그러나 내시경 삽입 관련 합병증은 측시경에서 더 흔하였다 $(0 \%$ vs. $18 \%, p<0.05){ }^{25}$

Roux-en-Y 재건술을 받은 환자는 보통 길이의 내시경으로는 유두에 도달하기 어렵지만, ${ }^{26}$ 풍선 소장내시경을 사용하면 85-95\%에서 유두부에 도달할 수 있다. ${ }^{24}$

변형된 해부학을 가진 환자에서는 EST를 시행하지 않고
내시경 유두 풍선확장술(endoscopic papillary balloon dilation)만을 이용하여 6-8 mm로 담관을 확장할 수 있다. 이러한 EST 및 내시경 유두 풍선 확장술의 무작위 대조 시험에서 시술 시간 및 기계적 쇄석술 빈도, 초기 부작용 발생률에서 EST 및 내시경 유두 풍선확장술군에서 차이가 없었다. ${ }^{27}$

\section{7. $\mathrm{ERCP}$ 관련 합병증}

ERCP는 여러 합병증을 동반할 수 있다. 2020년 발표한 European Society of Gastrointestinal Endoscopy 가이드라인에서 정리한 $\mathrm{ERCP}$ 관련 합병증은 Table 2 와 같다. ${ }^{6} \mathrm{EST}$ 관련 조기 부작용은 출혈, 천공, 췌장염, 담관염 등이 보고되며 $3-11.8 \%$ 에서 발생하였다. 부작용의 발생 빈도는 급성 췌장염이 $0.5-6.9 \%$, 출혈이 $0-27 \%$, 천공 $0-1.8 \%$, 담관염이 $0-4.2 \%$ 에서 보고된다.

Table 2. Incidence, mortality and severity grading of the most common ERCP-related adverse events (modified from Dumonceau et al. ${ }^{6}$ )

\begin{tabular}{|c|c|c|c|c|c|}
\hline \multirow{2}{*}{ 유형 } & \multirow{2}{*}{ 유병률 } & \multirow{2}{*}{ 사망률 } & \multicolumn{3}{|c|}{ 중증도 } \\
\hline & & & 경증 & 중등증 & 중증 \\
\hline 췌장염 & $3.5-9.7 \%$ & $0.1-0.7 \%$ & $\begin{array}{l}\text { - 장기 부전이 없는 경우 } \\
\text { - 국소 또는 전신 합병증이 } \\
\text { 없는 경우 }\end{array}$ & $\begin{array}{l}\text { - 일과성 }(<48 \text { 시간 }) \text { 장기 부전 } \\
\text { - 지속적 장기 부전을 동반하지 } \\
\text { 않은 국소 또는 전신 합병증 }\end{array}$ & - 지속성(48시간) 장기 부전 \\
\hline 담관염 & $0.5-3.0 \%$ & $0.1 \%$ & - 경증 담관염 & $\begin{array}{l}\text { 다음 중 한가지 이상: } \\
\text { - 백혈구 }>12,000 \text { or } \\
\quad<4,000 / \mathrm{mm}^{3} \\
\text { - 발열 } \geq 39^{\circ} \mathrm{C} \\
\text { - 연령 } \geq 75 \text { 세 } \\
\text { - 총빌리루빈 } \geq 5 \mathrm{mg} / \mathrm{dL} \\
\text { - 저알부민혈증 }\end{array}$ & $\begin{array}{l}\text { 다음 중 한 가지 이상의 기능 부전: } \\
\text { - 심혈관계 } \\
\text { - 신경계 } \\
\text { - 호흡기계 } \\
\text { - 신장 } \\
\text { - 간 } \\
\text { - 혈액학적 }\end{array}$ \\
\hline 담낭염 & $0.5-5.2 \%$ & $0.04 \%$ & - 경증 담낭염 & $\begin{array}{l}\text { 다음 중 한 가지 이상: } \\
\text { - 백혈구 }>18,000 / \mathrm{mm}^{3} \\
\text { - 우상복부의 압통을 동반한 종괴 } \\
\text { - 72시간 이상 지속 } \\
\text { - 국소 염증 소견(괴저성 담낭 } \\
\text { 염, 담낭 주위 농양, 간농양, } \\
\text { 담즙 복막염, 기종성 담낭염) }\end{array}$ & $\begin{array}{l}\text { 다음 중 한 가지 이상의 기능 부전: } \\
\text { - 심혈관계 } \\
\text { - 신경계 } \\
\text { - 호흡기계 } \\
\text { - 신장 } \\
\text { - 간 } \\
\text { - 혈액학적 }\end{array}$ \\
\hline 출혈 & $0.3-9.6 \%$ & $0.04 \%$ & $\begin{array}{l}\text { 다음 중 한 가지: } \\
\text { - 시술 실패 } \\
\text { - 4일 이내의 입원 기간의 } \\
\text { 연장 }\end{array}$ & $\begin{array}{l}\text { 다음 중 한 가지 이상: } \\
\text { - 4-10일의 입원 기간 연장 } \\
\text { - 1일의 중환자실 입원 } \\
\text { - 수혈 필요성 } \\
\text { - 내시경 또는 방사선학적 } \\
\quad \text { 시술의 반복 }\end{array}$ & $\begin{array}{l}\text { 다음 중 한 가지 이상: } \\
\text { - } 10 \text { 일 이상의 입원 기간 연장 } \\
\text { - } 1 \text { 일 이상 중환자실 입원 } \\
\text { - 수술 필요성 } \\
\text { - 영구 장애 }\end{array}$ \\
\hline 천공 & $0.08-0.6 \%$ & $0.06 \%$ & 출혈 항목과 동일 & 출혈 항목과 동일 & 출혈 항목과 동일 \\
\hline $\begin{array}{c}\text { 진정 관련 } \\
\text { 합병증 }\end{array}$ & $24.6 \%$ & $0.02 \%$ & 출혈 항목과 동일 & 출혈 항목과 동일 & 출혈 항목과 동일 \\
\hline
\end{tabular}

ERCP, endoscopic retrograde cholangiopancreatography. 


\section{1) 췌장염}

ERCP 후 췌장염(post-ERCP pancreatitis) 발생의 시술 관련 위험인자로는 유두 부종으로 인한 췌장 울혈 및 췌관압 증가, 기구로 인한 췌관 손상, 췌관 내 조영제 주입, 췌관 입구의 열손상 등이 있으며 실제 발생에는 여러 요소가 복합적으로 영향을 미치는 것으로 여겨진다. ${ }^{28}$ 환자 관련 위험인자로는 Oddi 괄약근 기능장애, 여성, 췌장염의 과거력, 35 세 미만의 연령 등이 독립적 위험인자로 알려져 있다. ${ }^{29}$ 인구 기반 연구에 따르면 EST 역시 ERCP 후 췌장염의 독립적인 위험인자였다. ${ }^{30}$

ERCP 후 췌장염을 예방하기 위하여 예방적 췌관 스텐트 삽관, 직장 비스테로이드 항염증제 투여 등이 고려되며, 췌장 효소 억제제, 소마토스타틴 및 옥트레오타이드, 니트로글리세린 투여 및 유두에 에피네프린 분무 등의 약물 치료는 예방에 큰 효과가 없는 것으로 보고되었다. ${ }^{31}$ 2020년 European Society of Gastrointestinal Endoscopy에서는 금기가 없는 모든 ERCP를 받는 환자에게 시술 직전 $100 \mathrm{mg}$ 의 디클로페낙이나 인도메탁신을 경직장 투여를 권장하였다. ${ }^{6}$ 다양한 투여 경로를 비교하였을 때 경직장 투여만이 효과적으로 나타났다. ${ }^{6}$ 비스테로이드 항염증제의 투여 시기에 대해서는 ERCP 전후 투여를 비교하였을 때 췌장염은 $6 \%$ vs. $12 \%$ 로 발생하여(RR $0.47 ; 95 \%$ CI 0.27-0.82), ERCP 전 비스테로이드 항염증제 투여가 ERCP 후 췌장염 예방에 더 효과적임을 보여주었다. ${ }^{32}$ 아스피린이나 클로피도그렐을 복용하고 있는 환자에서 $100 \mathrm{mg}$ 의 인도메탁신 단일 투여는 EST 후 출혈 위험성을 증가시키지 않았다. ${ }^{33}$

또한 같은 가이드라인에서 $\mathrm{ERCP}$ 중 유도 철선의 췌관 삽관 또는 췌관 내 조영제 투여, 이중 유도철선 삽관법 등 $\mathrm{ERCP}$ 후 췌장염 발생 위험이 높은 경우에는 예방적 췌관 스텐트를 유치할 것을 권고하였다. ${ }^{6}$ 2011년부터 2019년 사이 발표된 8 개의 메타분석에서 예방적 췌관 스텐트 삽관이 PEP 발생률 감소와 관련이 있었다(OR 0.22-0.39). ${ }^{6}$ 또한 중증 $\mathrm{PEP}$ 와 관련한 메타분석에서도 PEP 발생률을 현저히 감소시켰다 $(\mathrm{OR}$ 0.22-0.26). ${ }^{6}$ 비용-효율 분석에서는 예방적 췌관 스텐트를 고위험 환자에게 국한하여 사용하는 것이 가장 비용-효율적인 전략임을 보여주었다. ${ }^{6}$ 예방적 췌관 스텐트는 십이지장 쪽에만 플린지가 있거나 $5 \mathrm{Fr}$ 돼지꼬리형 스텐트의 사용이 제안되며 5-10일 이내에 췌관 스텐트를 평가한 후 제거해야 한다. ${ }^{6}$

European Society of Gastrointestinal Endoscopy 가이드라인 에서는 또한 심부전이나 신부전 등 체액 과잉증의 위험성이 없고 췌관 스텐트를 유치하지 못한 비스테로이드 항염증제
금기 환자에게는 젖산 링거 용액 $(3 \mathrm{~mL} / \mathrm{kg} /$ hour during ERCP, $20 \mathrm{~mL} / \mathrm{kg}$ bolus after ERCP, $3 \mathrm{~mL} / \mathrm{kg} /$ hour for 8 hours after $\mathrm{ERCP})$ 으로 적극적인 수액요법을 할 것을 권고하였다. ${ }^{6}$

\section{2) 출혈}

2020년 European Society of Gastrointestinal Endoscopy 가이드라인에 따르면 출혈의 위험인자로는 항응고제 복용, 혈소판 수 $<50,000 / \mathrm{mm}^{3}$, 간경화, 말기 신부전에 의한 투석 중인 환자, $\mathrm{ERCP}$ 중 출혈 등의 인자 중 적어도 하나 이상 존재하는 경우 출혈 위험이 증가한 것으로 간주해야 한다. ${ }^{6}$ 출혈 발생 시 1 차 치료는 내시경 지혈술이 고려된다. 5 단위 이상의 수혈이 필요하거나 지혈술이 필요한 중증 출혈은 0.1-0.5\%에서 발생한다. ${ }^{34}$ 내시경 지혈술에는 국소 압박법, 국소 주입법, 응고법, 클립 지혈술 등이 사용된다. ${ }^{35}$ 풍선 카테터 또는 내시경 유두 풍선확장술을 이용한 국소 압박은 비교적 쉽고 효과적인 방법이다. 국소 고장성 생리식염수 에피네프린 용액 주입법 (hypertonic saline-epinephrine solution) 또한 비교적 안전하고 효과적이나 점막 손상 및 부종으로 췌장염을 일으킬 수 있고 천공 발생도 가능하여 시술 시 주의가 필요하다. ${ }^{36}$ 또 다른 방법으로 발열 프로브(heat probe), 아르곤 플라즈마 지혈술(argon plasma coagulation) 및 클립 지혈술 등을 이용할 수 있으나 췌관 입구에 손상이 발생할 수 있어 주의 깊게 시행되어야 한다. ${ }^{37}$

\section{3) 천공}

천공의 위험인자로는 변형된 해부학적 구조, 유두 병변의 존재, EST, 담도 협착의 확장술, 확장된 담관, Oddi 괄약근 기능 부전, 예비 절개술 등이 있다. ${ }^{6}$ 특히 Billroth II의 경우 후향적 연구에서 천공과 관련이 있음을 보여주었다. ${ }^{38}$ 천공 발생이 의심되는 경우엔 computed tomography를 시행해야 한다. 외과적 치료가 필요한 천공은 0.2-0.7\%에서 발생하며 $0.2-0.3 \%$ 에서 사망이 보고되었다. ${ }^{7.34}$ 천공의 크기가 작을 경우 담관 배액, 췌관 배액, 비위관 배액 등의 보존적 치료를 통해 호전되는 경우가 많다. ${ }^{39}$ 그러나 보존적 치료로 24 시간 이내에 호전되지 않는 경우 외과적 치료가 필요하며 진단 및 치료가 지연되는 경우 예후가 좋지 않다. ${ }^{39,40}$

\section{8. 담관 결석 제거율}

EST와 유두 풍선확장술의 결석 제거율에 대한 무작위 비교 
연구는 절개술을 시행한 군에서 결석 제거율이 더 높았으며 첫 시술 시 결석 제거율은 56.2-92.7\%, 최종적인 완전 결석 제거율은 86.8-100\%로 보고하였다. ${ }^{41} \mathrm{EST}$ 와 유두 큰풍선확장술(endoscopic papillary large balloon dilation)을 비교한 연구의 경우에서는 91-100\%로 유의한 차이를 보이지 않았다. ${ }^{42} \mathrm{EST}$ 후 담관 결석 재발률은 4.1-17\%로, 5년 재발률은 $9.6 \%, 10$ 년 재발률은 $13.2 \%$ 로 보고하였다. 담관 결석 재발의 위험인자에는 담관 내 부종, 담관 확장, 담낭 담석의 존재, 십이지장 유두 주위 게실 및 기계적 쇄석술을 시행한 경우 등이 있으며, ${ }^{43}$ 담관 결석의 재발은 재발의 횟수가 늘어날수록 증가하는데, 1 회 재발 후 $23.4 \%$, 2회 재발 후 $33.4 \%$ 로 급격히 증가한다. ${ }^{44,45}$ 담관 결석 재발의 경우 내시경을 통한 치료가 우선 권장된다. 또한 담낭석이 있는 경우 담낭 절제술로 부분적으로 예방할 수 있다. ${ }^{46}$ 담낭 절제는 특히 젊은 환자에게 효과적이며 70 세 이상의 경우 RR이 1.26 인데 비하여 50 세 미만에서는 3.20 으로 알려져 있다. ${ }^{44}$ 불완전한 결석 제거, 원발성 담도 경화증, 간문부 폐쇄와 60세 이상의 연령, 이전의 $\mathrm{ERCP}$ 시행력 및 담도경은 ERCP 후 담관염 발생에 독립적 위험인자였으며, 반대로 완전한 담도 결석 제거는 담관염 발생을 줄여주었다. ${ }^{47}$

\section{9. 플라스틱 스텐트 또는 자가팽창형 금속 스텐트 삽입술}

2020년 European Society of Gastrointestinal Endoscopy 가이드라인에서는 단일 플라스틱 스텐트나 자가팽창형 금속 스텐트(self-expandable metal stent)를 삽입할 경우 일상적인 EST를 시행하지 말 것을 권고하였다. ${ }^{6} \mathrm{ERCP}$ 전 예방적 항생제 역시 일상적으로 사용하지 말 것을 권고하였고, 불완전한 담관 배액이 예상되거나 심각한 면역 저하자 및 담관경 검사를 시행할 경우에 항생제 투여를 권고하였다. ${ }^{6}$ 또한 항응고제를 사용하지 않고 황달이 없는 환자의 경우 ERCP 전 획일적으로 혈액응고 검사를 시행하는 것은 무의미하다고 하였다. ${ }^{6} \mathrm{ERCP}$ 후 췌장염이 발생한 경우 환자가 심각한 통증을 호소하거나 10 배 이상의 아밀라아제 상승, 백혈구나 C-반응단백(C-reactive protein) 상승 등의 경우에만 선택적인 구제요법으로 췌관 스텐트 삽관을 시도할 수 있다. ${ }^{6} \mathrm{EST}$ 후 일반적인 지혈술에도 지속적으로 출혈이 있는 경우 피막형 금속 스텐트(fully covered self expandable metallic stent)를 일시적으로 삽입하여 치료해 볼 것을 권고하였다. ${ }^{6}$

\section{결 론}

$\mathrm{ERCP}$ 는 다양한 담도 및 췌장 질환의 진단과 치료에 있어 중요한 시술이다. 그러나 시술의 난이도가 높고 드물지만 때로는 심각한 합병증을 일으킬 수 있어 적절한 대처를 하지 않을 경우 환자의 생명을 위험하게 할 수 있다. 따라서 췌장담도 질환에 대한 정확한 이해가 우선되어야 하며 시술의 적응이 되는 환자를 선별할 수 있어야 한다. 시술자는 적절한 ERCP 수행 능력이 요구되며 여러 술기에 대해 이해하고 가이드라인에 따른 안전한 시술이 필요하다. 또한 합병증이 발생한 경우 이를 적절히 대처할 수 있어야 한다. 내시경으로 대처가 어려운 경우 혈관 색전술이나 수술 등 다학제 간 긴밀한 협조가 필요하다. 본고에서는 다양한 ERCP 관련한 가이드라인 내용을 정리해보았으며 향후 $\mathrm{ERCP}$ 를 시작하는 의사들에게 도움이 될 수 있으리라 기대한다.

\section{요 약}

내시경역행담췌관조영술(ERCP)은 다양한 췌장담도 질환의 진단과 치료에 있어 기본적이며 중요한 시술이다. 그러나 $\mathrm{ERCP}$ 는 시술의 위험 요소가 크며, 여러 합병증을 동반할 수 있다. 이에 시술자는 적절한 $\mathrm{ERCP}$ 수행 능력이 요구되며 여러 술기에 대해 이해하고 가이드라인에 따른 안전한 시술이 필요하며 발생한 합병증에 적절히 대처할 수 있어야 한다.

국문 색인: 내시경역행담췌관조영술, 치료, 합병증

\section{Conflicts of Interest}

The authors have no conflicts to disclose.

\section{REFERENCES}

1. Appropriate use of gastrointestinal endoscopy. American Society for Gastrointestinal Endoscopy. Gastrointest Endosc 2000;52:831-837.

2. Freeman ML, Guda NM. ERCP cannulation: a review of reported techniques. Gastrointest Endosc 2005;61:112-125.

3. ASGE Technology Committee, Kethu SR, Adler DG, et al. ERCP cannulation and sphincterotomy devices. Gastrointest Endosc 2010;71:435445.

4. Laasch HU, Tringali A, Wilbraham L, et al. Comparison of standard and steerable catheters for bile duct cannulation in ERCP. Endoscopy 2003:35:669-674. 
5. Clayton ES, Connor S, Alexakis N, Leandros E. Meta-analysis of endoscopy and surgery versus surgery alone for common bile duct stones with the gallbladder in situ. Br J Surg 2006;93:1185-1191.

6. Dumonceau JM, Kapral C, Aabakken L, et al. ERCP-related adverse events: European Society of Gastrointestinal Endoscopy (ESGE) guideline. Endoscopy 2020;52:127-149.

7. Freeman ML, Nelson DB, Sherman S, et al. Complications of endoscopic biliary sphincterotomy. N Engl J Med 1996;335:909-918.

8. Hamada $T$, Yasunaga $H$, Nakai $Y$, et al. Bleeding after endoscopic sphincterotomy or papillary balloon dilation among users of antithrombotic agents. Endoscopy 2015;47:997-1004.

9. Kim KO, Kim TN, Kim SB, Lee JY. Characteristics of delayed hemorrhage after endoscopic sphincterotomy. J Gastroenterol Hepatol 2010;25:532-538.

10. Verma D, Kapadia A, Adler DG. Pure versus mixed electrosurgical current for endoscopic biliary sphincterotomy: a meta-analysis of adverse outcomes. Gastrointest Endosc 2007;66:283-290.

11. Mirjalili SA, Stringer MD. The arterial supply of the major duodenal papilla and its relevance to endoscopic sphincterotomy. Endoscopy 2011:43:307-311.

12. Petersen $B T$, Hussain N, Marine JE, et al. Endoscopy in patients with implanted electronic devices. Gastrointest Endosc 2007;65:561-568.

13. Tse F, Yuan Y. Early routine endoscopic retrograde cholangiopancreatography strategy versus early conservative management strategy in acute gallstone pancreatitis. Cochrane Database Syst Rev 2012;(5):CD009779.

14. Harewood GC, Baron TH. An assessment of the learning curve for precut biliary sphincterotomy. Am J Gastroenterol 2002;97:17081712.

15. Lehman GA. What are the determinants of success in utilization of ERCP in the setting of pancreatic and biliary diseases?. Gastrointest Endosc 2002;56(Suppl 6):S291-S293.

16. Yasuda I, Isayama H, Bhatia V. Current situation of endoscopic biliary cannulation and salvage techniques for difficult cases: current strategies in Japan. Dig Endosc 2016;28 Suppl 1:62-69.

17. Dhir V, Bhandari S, Bapat M, Maydeo A. Comparison of EUS-guided rendezvous and precut papillotomy techniques for biliary access (with videos). Gastrointest Endosc 2012;75:354-359.

18. Isayama $H$, Nakai $Y$, Koike $K$. Is a guidewire a magic wand? Is a knife the final weapon?. Saudi J Gastroenterol 2015;21:3-4.

19. Zoepf T, Zoepf DS, Arnold JC, Benz C, Riemann JF. The relationship between juxtapapillary duodenal diverticula and disorders of the biliopancreatic system: analysis of 350 patients. Gastrointest Endosc 2001;54:56-61.

20. Fujita N, Noda Y, Kobayashi G, Kimura K, Yago A. ERCP for intradiverticular papilla: two-devices-in-one-channel method. Endoscopic retrograde cholangiopancreatography. Gastrointest Endosc 1998;48:517520.

21. Scotiniotis I, Ginsberg GG. Endoscopic clip-assisted biliary cannula- tion: externalization and fixation of the major papilla from within a duodenal diverticulum using the endoscopic clip fixing device. Gastrointest Endosc 1999;50:431-436.

22. Bove $V$, Tringali A, Familiari $P$, et al. ERCP in patients with prior Billroth II gastrectomy: report of 30 years' experience. Endoscopy 2015;47:611-616.

23. Itoi $T$, Ishii $K$, Sofuni $A$, et al. Single-balloon enteroscopy-assisted ERCP in patients with Billroth II gastrectomy or Roux-en-Y anastomosis (with video). Am J Gastroenterol 2010;105:93-99.

24. Shimatani M, Matsushita M, Takaoka M, et al. Effective "short" double-balloon enteroscope for diagnostic and therapeutic ERCP in patients with altered gastrointestinal anatomy: a large case series. Endoscopy 2009;41:849-854.

25. Kim MH, Lee SK, Lee MH, et al. Endoscopic retrograde cholangiopancreatography and needle-knife sphincterotomy in patients with Billroth II gastrectomy: a comparative study of the forward-viewing endoscope and the side-viewing duodenoscope. Endoscopy 1997;29:82-85.

26. Hintze RE, Veltzke W, Adler A, Abou-Rebyeh H. Endoscopic sphincterotomy using an S-shaped sphincterotome in patients with a Billroth II or Roux-en-Y gastrojejunostomy. Endoscopy 1997;29:74-78.

27. Bergman JJ, van Berkel AM, Bruno MJ, et al. A randomized trial of endoscopic balloon dilation and endoscopic sphincterotomy for removal of bile duct stones in patients with a prior Billroth II gastrectomy. Gastrointest Endosc 2001;53:19-26.

28. Ding $X$, Zhang F, Wang Y. Risk factors for post-ERCP pancreatitis: a systematic review and meta-analysis. Surgeon 2015;13:218-229.

29. El Nakeeb A, El Hanafy E, Salah T, et al. Post-endoscopic retrograde cholangiopancreatography pancreatitis: risk factors and predictors of severity. World J Gastrointest Endosc 2016;8:709-715.

30. Njei B, Sharma P, McCarty TR, et al. Cannabis use is associated with increased risk of post-endoscopic retrograde cholangiopancreatography pancreatitis: analysis of the US nationwide inpatient sample database, 2004-2014. Pancreas 2018;47:1142-1149.

31. Freeman ML, Guda NM. Prevention of post-ERCP pancreatitis: a comprehensive review. Gastrointest Endosc 2004;59:845-864.

32. Luo H, Zhao L, Leung J, et al. Routine pre-procedural rectal indometacin versus selective post-procedural rectal indometacin to prevent pancreatitis in patients undergoing endoscopic retrograde cholangiopancreatography: a multicentre, single-blinded, randomised controlled trial. Lancet 2016;387:2293-2301.

33. Patai Á, Solymosi N, Patai ÁV. Does rectal indomethacin given for prevention of post-ERCP pancreatitis increase bleeding after biliary endoscopic sphincterotomy or cardiovascular mortality?: post hoc analysis using prospective clinical trial data. Medicine (Baltimore) 2014;93:e159.

34. Barthet M, Lesavre N, Desjeux A, et al. Complications of endoscopic sphincterotomy: results from a single tertiary referral center. Endoscopy 2002;34:991-997. 
35. Ferreira LE, Baron TH. Post-sphincterotomy bleeding: who, what, when, and how. Am J Gastroenterol 2007;102:2850-2858.

36. Wilcox CM, Canakis J, Mönkemüller KE, Bondora AW, Geels W. Patterns of bleeding after endoscopic sphincterotomy, the subsequent risk of bleeding, and the role of epinephrine injection. Am J Gastroenterol 2004;99:244-248.

37. Kuran S, Parlak E, Oguz D, Cicek B, Disibeyaz S, Sahin B. Endoscopic sphincterotomy-induced hemorrhage: treatment with heat probe. Gastrointest Endosc 2006;63:506-511.

38. Takano S, Fukasawa M, Shindo H, et al. Risk factors for perforation during endoscopic retrograde cholangiopancreatography in postreconstruction intestinal tract. World J Clin Cases 2019;7:10-18.

39. Fatima J, Baron TH, Topazian MD, et al. Pancreaticobiliary and duodenal perforations after periampullary endoscopic procedures: diagnosis and management. Arch Surg 2007;142:448-455.

40. Morgan KA, Fontenot BB, Ruddy JM, Mickey S, Adams DB. Endoscopic retrograde cholangiopancreatography gut perforations: when to wait! When to operate!. Am Surg 2009;75:477-484.

41. Weinberg BM, Shindy W, Lo S. Endoscopic balloon sphincter dilation (sphincteroplasty) versus sphincterotomy for common bile duct stones. Cochrane Database Syst Rev 2006;(4):CD004890.
42. Feng $Y$, Zhu H, Chen $X$, et al. Comparison of endoscopic papillary large balloon dilation and endoscopic sphincterotomy for retrieval of choledocholithiasis: a meta-analysis of randomized controlled trials. J Gastroenterol 2012;47:655-663.

43. Fujimoto T, Tsuyuguchi T, Sakai Y, et al. Long-term outcome of endoscopic papillotomy for choledocholithiasis with cholecystolithiasis. Dig Endosc 2010;22:95-100.

44. Park BK, Seo JH, Jeon HH, et al. A nationwide population-based study of common bile duct stone recurrence after endoscopic stone removal in Korea. J Gastroenterol 2018;53:670-678.

45. Konstantakis C, Triantos C, Theopistos V, et al. Recurrence of choledocholithiasis following endoscopic bile duct clearance: long term results and factors associated with recurrent bile duct stones. World J Gastrointest Endosc 2017;9:26-33.

46. Khan MA, Khan Z, Tombazzi CR, Gadiparthi C, Lee W, Wilcox CM. Role of cholecystectomy after endoscopic sphincterotomy in the management of choledocholithiasis in high-risk patients: a systematic review and meta-analysis. J Clin Gastroenterol 2018;52:579-589.

47. Chen $M$, Wang $L$, Wang $Y$, et al. Risk factor analysis of post-ERCP cholangitis: a single-center experience. Hepatobiliary Pancreat Dis Int 2018;17:55-58. 